\title{
Telaah Kurikulum dalam Mata Pelajaran Al-Qur'an Hadist di Madrasah Ibtidaiyah
}

\author{
Purniadi Putra \\ IAIS Sultan Muhammad Syafiuddin Sambas \\ Kalimantan Barat \\ Email: usupurniadi@yahoo.com

\section{Idawati} \\ Fakultas Ilmu Tarbiyah dan Keguruan \\ Universitas Islam Negeri Raden Fatah Palembang \\ E-mail: idawati_uin@radenfatah.ac.id
}

\begin{abstract}
The curriculum of Al-Qur'an Hadith in MI developed is expected to ensure the growth of faith and devotion towards Allah SWT, improvement of life skills, ability to work and be scientific while ensuring the development of a strong personality and berakhlaq noble. Method: This research using literature approach (libarary research). The subject of this research is the curriculum at the grade of 1,2 and 3 in Madrasah Ibtidaiyah. Results: For the basic competencies presented in classes 1,2 and 3 can not be implemented maximally because the basic competence mentioned learners are required to pronounce and memorize short verses correctly and eloquently.
\end{abstract}

Abstrak: Kurikulum Al-Qur'an Hadis di MI yang dikembangkan diharapkan mampu menjamin pertumbuhan keimanan dan ketaqwaan terhadap Allah SWT, peningkatan kecakapan hidup, kemampuan bekerja dan bersikap ilmiah sekaligus menjamin pengembangan kepribadian yang kuat dan berakhlaq mulia. Metode: penelitian ini dengan menggunakan pendekatan kepustakaan (libarary research). Subjek penelitian ini adalah kurikulum ditingkat kelas 1,2 dan 3 di Madrasah Ibtidaiyah. Hasil: Untuk kompetensi dasar yang disajikan di kelas 1, 2 dan 3 belum bisa dilaksanakan secara maksimal karena kompetensi dasar tersebut menyebutkan peserta didik diharuskan dapat melafalkan dan menghafalkan ayat-ayat pendek secara benar dan fasih

Kata Kunci: Telaah Kuikulum, Al-Qur'an Hadis di MI

\section{A. Pendahuluan}

Sebuah pendidikan harus bertumpu pada basis kompetensi yang dikembangkan di Madrasah. Kompetensi yang harus dimiliki dapat menjamin pertumbuhan keimanan dan ketaqwaan kepada Allah Swt, penguasaan life skill, pengusaan kemampuan akademik, seni, dan pengembangan kepribadian yang paripurna. Dengan pertimbangan ini, maka disusun kurikulum nasional Pendidikan Agama di Madrasah yang berbabasis kompetensi dasar yang mencerminkn kebutuhan keberagaman peserta didik Madrasah secara nasional. Standar ini diharapkan dapat dipergunakan sebagai acuan dalam mengembangkan kurikulum Qur'an Hadis di Madrasah sesuai dengan kebutuhan daerah/ Madrasah.

Oleh karena itu, peranan dan efektifitas pendidikan agama di Madrasah sebagai landasan bagi pengembangan spiritual terhadap kesejahteraan masyarakat mutlak harus 
ditingkatkan, karena asumsinya adalah jika pendidikan agama (Yang meliputi AlQur'an dan Hadist, Aqidah dan Akhlaq, Fiqih dan Sejarah Kebudayaan Islam) yang dijadikan landasan pengembangan nilai spiritual dilakukan dengan baik, maka kehidupan masyarakat akan lebih baik. Pendidikan Al-Qur'an dan Hadis di Madrasah Ibtidaiyah sebagai landasan yang integral dari pendidikan Agama, memang bukan satusatunya faktor yang menentukan dalam pembentukan watak dan kepribadian peserta didik, tetapi secara substansial mata pelajaran Al-Qur'an dan hadis memiliki kontribusi dalam memberikan motivasi kepada peserta didik untuk mempraktekkan nilai-nilai keyakinan kegamaan (tauhid) dan akhlaqul karimah dalam kehidupan sehari-hari. (Fahrurozi, 2016).

Di dalam UU No. 20 Tahun 2003 tentang Sistem Pendidikan Nasional, dinyatakan bahwa pendidikan nasional berfungsi mengembangkan kemampuan dan membentuk watak serta peradaban bangsa yang bermartabat dalam rangka mencerdaskan kehidupan bangsa, bertujuan untuk berkembangnya potensi peserta didik agar menjadi manusia yang beriman dan bertakwa kepada Tuhan Yang Maha Esa, berakhlak mulia, sehat, berilmu, cakap, kreatif, mandiri, dan menjadi warga negara yang demokratis serta bertanggung jawab. Untuk mencapai tujuan tersebut, salah satu bidang studi yang harus dipelajari oleh peserta didik di madrasah adalah Pendidikan Agama Islam, yang dimaksudkan untuk membentuk peserta didik menjadi manusia yang beriman dan bertakwa kepada Tuhan Yang Maha Esa serta berakhlak mulia. (Departemen Agama RI Kurikulum, 2006).

Pendidikan Agama Islam di Madrasah Ibtidaiyah terdiri atas empat mata pelajaran, yaitu: al-Qur'an-Hadis, Akidah-Akhlak, Fiqih, dan Sejarah Kebudayaan Islam. Mata pelajaran tersebut pada dasarnya saling terkait, isi mengisi dan melengkapi. Al-Qur'an-Hadist merupakan sumber utama ajaran Islam, dalam arti merupakan sumber akidah akhlak, syari'ah/fiqih (ibadah, muamalah), sehingga kajian berada di setiap unsur tersebut.

Empat mata pelajaran PAI di Madrasah Ibtidaiyah memiliki karakteristik tersendiri. Pada mata pelajaran Al-Qur'an-Hadis, menekankan pada kemampuan baca tulis yang baik dan benar, hapalan terhadap surat-surat pendek dalam al-Qur'an, memahami makna secara tekstual dan kontekstual, serta mengamalkan kandungannya dalam kehidupan sehari-hari dengan pengenalan arti atau makna secara sederhana dari surat-surat pendek tersebut dan hadis-hadis tentang akhlak terpuji untuk diamalkan dalam kehidupan sehari-hari melalui keteladanan dan pembiasaan. Hal ini sejalan dengan misi pendidikan dasar/MI adalah untuk:

a. Pengembangan potensi dan kapasitas belajar peserta didik.

b. Pengembangan kemampuan baca-tulis-hitung (CALISTUNG) dan bernalar, keterampilan hidup.

Secara substansial mata pelajaran Al-Qur'an-Hadist memiliki kontribusi dalam memberikan motivasi kepada peserta didik untuk mencintai kitab sucinya, mempelajari dan mempraktikkan ajaran dan nilai-nilai yang terkandung dalam al-Qur'an-Hadis sebagai sumber utama ajaran Islam dan sekaligus menjadi pegangan dan pedoman hidup 
dalam kehidupan sehari-hari. Dalam materi Al-Quran hadis juga mendorong tumbuhnya kajian tentang pengembangan bahasa Arab.

Dalam Depertemen Agama RI, (2016), sesuai dengan kerangka pikir dalam kurikulum Al-Qur'an dan Hadist Madrasah Ibtidaiyah (MI) dikekmbangkan dengan pendekatan sebagai berikut:

a. Lebih menitikberatkan target kompetensi dari penguasaan materi.

b. Lebih mengakomodasikan keragaman kebutuhan dan sumber daya pendidikan yang tersedia

c. Memberikan kebebasan yang lebih luas kepada pelaksanaan pendidikan di lapangan untuk mengembangkan dan melaksanakan program pembelajaran sesuai dengan kebutuhan.

Direktorat Pendidikan Madrasah, Depag, (2007), menyajikan beberapa pendekatan yang dapat dijadikan acuan dalam proses pembelajaran Al-Qur'an Hadis, yaitu:

a. Pendekatan keimanan/spiritual.

b. Pendekatan pengamalan.

c. Pendekatan pembiasaan.

d. Pendekatan rasional.

e. Pendekatan emosional.

f. Pendekatan fungsional.

g. Pendekatan keteladanan.

Kurikulum Al-Qur'an Hadis di Madrasah Ibtidaiyah yang dikembangkan dengan pendekatan tersebut diharapkan mampu menjamin pertumbuhan keimanan dan ketaqwaan terhadap Allah SWT, peningkatan penguasaan kecakapan hidup, kemampuan bekerja dan bersikap ilmiah sekaligus menjamin pengembangan kepribadian Indonesia yang kuat dan berakhlaq mulia.

Pembelajaran Al-Qur'an-Hadis di Madrasah Ibtidaiyah bertujuan untuk memberikan kemampuan dasar kepada peserta didik dalam membaca, menulis, membiasakan dan menggemari Al-Qur'an dan Hadis serta menanamkan pengertian, pemahaman, penghayatan isi kandungan ayat-ayat al-Qur'an Hadis untuk mendorong, membina dan membimbing akhlaq dan perilaku peserta didik agar berpedoman kepada isi kandungan ayat- ayat Al-Qur'an dan Hadis.

Mata pelajaran Al-Qur'an-Hadis pada Madrasah Ibtidaiyah berfungsi:

a. Menumbuh kembangkan kemampuan peserta didik membaca dan menulis AlQur'an-Hadis.

b. Mendorong, membimbing dan membina kemampuan dan kegemaran untuk membaca Al-Qur'an dan Hadis

c. Menanamkan pengertian, pemahaman, penghayatan dan pengamalan kandungan ayat-ayat Al-Qur'an dan Hadis dalam perilaku peserta didik sehari-hari.

d. Memberikan bekal pengetahuan untuk mengikuti pendidikan pada jenjang yang setingkat lebih tinggi (MTs).

Ruang lingkup pengajaran al-Qur'an-Hadis di Madrasah Ibtidaiyah meliputi: 
a. Pengetahuan dasar membaca dan menulis Al-Qur'an dan Hadis.

b. Hafalan surat-surat pendek

c. Pemahaman kandungan surat-surat pendek.

d. Hadis-hadis tentang kebersihan, niat, menghormati orang tua, persaudaraan, silaturrahim, taqwa, menyayangi anak yatim, shalat berjamaah, ciri-ciri orang munafik dan amal shaleh.

Aspek materi ajar dalam mata pelajaran Al-Qur'an Hadis meliputi pengetahuan, sikap, dan keterampilan yang harus dipelajari siswa dalam rangka mencapai standar kompotensi yang telah ditentukan. Hal senada juga diungkapkan oleh Joko Susilo, (2008) bahwa materi pembelajaran adalah pokok yang harus dipelajari siswa sebagai sarana pencapaian kemampuan dasar yang akan dinilai dengan menggunakan instrumen yang disusun bedasarkan indikator pencapaian belajar. Materi pembelajaran terdiri beberapa aspek, antara lain: (knowledge) pengetahuan, (Skill) keterampilan, dan (Attitude) sikap atau nilai.

a. Pengetahuan, yang meliputi fakta, konsep, prinsip, prosedur, keterampilan, dan sikap atau nilai.

b. Keterampilan, yaitu suatu kemampuan untuk melakukan suatu kegiatan atau pekerjaan tertentu, yang dapat berarti secara jasmani maupun rohani.

c. Sikap atau nilai, yang berkaitan dengan sikap atau minat untuk mengikuti materi pembelajaran yang disajikan guru, nilai-nilai berupa aspirasi terhadap sesuatu dan penyesuaian perasaan sosial.

Aspek-aspek tersebut hendaknya menjadi bahan pertimbangan dalam menentukan materi pembalajaran Al-Quran hadis dan rinciannya, suatu satuan bahasa yang telah ditentukan perlu dianalisis lebih lanjut tentang konsep-konsep yang terkandung dalam topik tersebut, prinsip-prinsip yang perlu disampaikan dan seterusnya.

Kriteria dan prosdur pemilihan materi pembelajaran Al-Qur'an Hadis di Madrasah Ibtidaiyah (MI) meliputi: pemilihan materi pembelajaran Al-Quran Hadis tentu saja harus sejalan dengan ukuran-ukuran (kriteria) yang digunakan untuk memilih isi kurikulum bidang studi yang bersangkutan kriteria pemilihan materi pelajaran yang akan dikembangkan dalam tujuan Intruksional dan yang mendasari penentuan strategi pembelajaran.

a. Kriteria tujuan instruksional suatu materi pelajaran yang terpilih dimaksudkan untuk mencapai tujuan Instruksional khusus atau tujuan-tujuan tingka laku. karena itu, materi tersebut supaya sejalan dengan tujuan-tujuan yang telah dirumuskan.

b. Materi pembelajaran supaya terjabat perincian materi pelajaran berdasarkan pada tuntunan dimana setiap TIK telah dirumuskan secara spesifik, dapat diamati dan diukur.

c. Relevan dengan Kebutuhan Siswa Kebutuhan siswa yang pokok adalah bahwa mereka ingin berkembang berdasarkan potensi yang dimiliki. 
d. Kesesuaian dengan kondisi masyarakat siswa dipersiapkan untuk menjadi anggota masyarakat yang berguna berdasarkan potensi yang dimiliki.

e. Materi pembelajaran mengandung segi-segi etika materi pembelajaran yang akan dipilih hendaknya mempertimbangkan segi perkembangan moral siswa.

f. Materi pembelajaran tersusun dalam ruang lingkup dan urutan yang sistematis dan logis setiap mata pelajaran disusun secara bulat dan menyeluruh, terbatas yang lingkupnya dan terpusat pada satu topik masalah tertentu.

g. Materi pembelajaran bersumber dari buku, guru yang ahli dan masyarakat

Dari beberapa aspek di atas tentang materi pembelajaran Al-Qur'an Hadis yang perlu kita perhatikan di dalam isi materi kurikulum Al-Quran-Hadis yaitu:

a. Pengetahuan dasar membaca dan menulis Al-Qur'an yang benar sesuai kaidah ilmu tajwid.

b. Hafalan surat-surat pendek dalam Al-Qur'an dan pemahaman sederhana tentang arti dan makna kandungannya serta pengalamannya melalui keteladanan dan pembiasaan dalam kehidupan sehari-hari.

c. Pemahaman dan pengalaman melalui keteladanan dan pembiasaan mengenai hadisthadist yang berkaitan dengan kebersihan, menghormati orangtua, shalat berjamaah, dan persaudaraan.

d. Hadist-hadis tentang kebersihan, niat, persaudaraan, silaturahim, taqwa, menyayangi anak yatim, shalat berjamaah, ciri-ciri orang munafik dan amal shaleh. (Perpus, IAIN Salatiga, 2016)

Dalam Depertemen RI, (2016: 20), tujuan pembelajaran Al-Qur'an Hadis menurut Kemenag RI No. 20 Tahun 2008 adalah:

a. Memberikan kemampuan dasar kepada peserta didik dalam membaca, menulis, membiasakan, dan menggemari membaca Al-Qur'an Hadis.

b. Memberikan pengertian, pemahaman, penghayatan isi kandungan ayat-ayat AlQur'an Hadis melalui keteladanan dan pembiasaan.

c. Membina dan membimbing perilaku peserta didik dengan berpedoman pada isi kandungan ayat al-Qur'an Hadis.

Didi Supriadie dan Deni Darmawan, (2012: 127), Strategi berasal dari kata strategos (Yunani) yang artinya memberdayakan semua unsur; seperti perencanaan, cara dan teknik dalam upaya mencapai sasaran.

Dalam Adri Efferi, 2009: 25) menyatakan bahwa suatu pengajaran yang berkaitan dengan suatu materi kurikulum tertentu prinsip peterlaksanaan dipengaruhi oleh empat komponen pokok yaitu pembawa materi, penyaji materi, pendekatan dan penerima materi. Pengaturan materi kurikulum tersebut dinamakan strategi belajar mengajar.

Berdasarkan beberapa pandangan di atas, selanjutnya dikemukakan pengertian tentang strategi belajar mengajar Qur'an hadits merupaka cara-cara yang akan dipilih dan digunakan oleh seorang pengajar untuk menyampaikan materi pembelajaran Qur'an 
Hadis, sehinga akan memudahkan peserta didik mencapai tujuan yang dikuasai diakhir kegiatan belajar.

Pemilihan strategi belajar mengajar pada dasarnya merupakan salah satu hal penting yang harus dipahami oeh setiap guru, mengingat proses belajar mengajar merupakan proses komuniksi multi arah antar siswa, guru, dan lingkungan belajar. Pemilihan strategi belajar mengajar yang akan digunakan dalam proses belajar mengajar harus berorientasi pada tujuan pembelajaran yang akan dicapai. Selain itu, harus disesuaikan dengan jenis materi, karakteristik peserta didik serta situasi dan kondisi dimana proses pembelajaran tersebut akan berlangsung. (Hamzah B. Uno dan Nurdin Mohammad).

Ada beberapa macam strategi belajar mengajar al-Quran hadis yaitu:

a. Strategi Pembelajaran Langsung adalah strategi menempatkan guru sebagai sumber belajar, dan cukup efektif digunakan untuk menyampaikan informasi dan membentuk keterampilan secara langkah demi langkah. Strategi ini umumnya digunakan untuk memperkenalkan strategi lain pada awal pembelajaran. (Ridwan Abdullah Sani, 2013: 148). Contoh: ceramah, demontrasi. Strategi pembelajaran langsung merupakan pembelajaran yang banyak diarahkan oleh guru. Strategi ini efektif untuk menentukan informasi atau membangun keterampilan tahap demi tahap. Pembelajaran langsung biasanya bersifat deduktif. (Abdul Majid, 2013: 73).

Menurut Abdul Majid, (2013: 73), pembelajaran tidak langsung ini berpusat pada peserta didik, dimana siswa aktif membangun pengetauan dan guru bertindak sebgai fasilitator. Strategi ini memungkinkan peserta didik untuk terlibat dalam mengamati, menyelidiki, membuat penjelasan berdasarkan data, membuat hipotesis dan sebagainya.

Strategi dalam pembelajaran tidak langsung adalah sebagai berikut:

a. Dalam strategi pembelajaran tidak langsung memperhatikan keterlibatan tinggi siswa dalam melakukan observasi, penyelidikan, penggambaran inferensi berdasarkan data, atau pembentukan hipotesis.

b. Peran guru beralih dari pencerahan menjadi fasilitator, pendukung, dan sumber personal.

c. Guru merancang lingkungan belajar, memberikan kesempatan kepada siswa untuk terlibat, dan jika memungkinkan memberikan umpan balik kepada siswa ketika mereka melakukan inkuiri.

d. Strategi pembelajaran tidak langsung mensyaratkan penggunaan bahan cetak, mencetak dan sumber-sumber manusia.

Sedangkan strategi pembelajaran interaktif adalah suatu cara atau teknik pembelajaran yang digunakan guru pada saat menyajikan bahan pelajaran, dimana guru menjadi pemeran utama dalam menciptakan situasi yang edukatif, yang interaktif antara guru dengan siswa, siswa dengan siswa dan dengan sumber pembelajaran dalam menunjang tercapainya tujuan belajar. (Abdul Majid, 2013: 84).

Menurut Suparman dan Tarhuri, pembelajaran interaktif memiliki karakteristik sebagai berikut: 
a. Adanya variasi kegiatan klasikal, kelompok, dan perseorangan

b. Keterlibatan mental (pikiran, perasaan)

c. Guru berperan sebagai fasilitator, nara sumber, dan manajer kelas yang demokratis

d. Menerapkan pola komunikasi banyak arah

e. Suasana kelas yang fleksibel, demokratis, menantang, dan tetap terkendali oleh tujuan

f. Potensi dapat menghasilkan dampak pengiring lebih efektif

g. Dapat digunakan di dalam maupun di luar kelas.

Strategi pembelajaran mandiri ini merupakan strategi untuk mengembangkan inisiatif peserta didik secra individual, rasa percaya diri, dan pengembangan diri peserta didik. Belajar mandiri dapat dimulai oleh peserta didik atau dengan bantuan guru, di mana guru memandu dan memantau perkembangan belajar yang dilakukan oleh peserta didikk secra mandiri. Strategi ini dapat digunkan untuk mengembangkan kemampuan peserta didik dalam membuat keputusan yang bertanggung jawab, menganalisis permasalahan, melakukan refleksi, dan melakukan tindakan yang bermanfaat.

Guru mata pelajaran Qur'an Hadits sebelum menentukan strategi harus memahami tujuan dari kegiatan belajar mengajar yang telah ditentukan. Hal yang sering luput dari perhatian yaitu bahwa Qu'ran Hadis merupakan jenis materi yang dominan akan aspek afektif. Sehingga ranah afektif siswa dalam kegiatan belajar mengajar di sini juga perlu diolah, tidak sekedar pada kognitif siswa. Guru yang profesional selain harus mampu memahami tujuan belajar mengajar, jenis materi, dan karakteristik individu siswa, ia juga harus mampu menggunakan strategi tersebut secara efektif dan efisien.

Adapun media pembelajaran Al-Qur'an hadis ini merupakan sebuah alat yang mempunyai fungsi menyampaikan pesan (Bovee, 1997). Media pembelajaran adalah sebuah alat yang berfungsi untuk menyampaikan pesan dalam pembelajaran. Pembelajaran adalah sebuah proses komunikasi antara pembelajar, pengajar dan bahan ajar. Komunikasi tidak akan berjalan tanpa bantuan sarana penyampai pesan atau media.

Bagi guru Al-Qur'an-Hadits yang akan menggunakan suatu media pembelajaran, perlu memahami prinsip-prinsip umum pemilihan format media. Prinsipprinsip pemilihan tersebut antara lain adalah:

a. Tidak satu pun media pendidikan yang digunakan untuk meniadakan media pembelajaran lainnya.

b. Pemakaian media pembelajaran tertentu seringkali cenderung lebih tepat dipergunakan untuk membantu menyajikan suatu pokok bahasan tertentu dan bukan semua pokok bahasan.

c. Tidak semua media pembelajaran dapat digunakan untuk semua jenis kegiatan belajar mengajar.

d. Penggunaan media pembelajaran yang banyak dalam suatu proses belajar mengajar dapat membingungkan siswa dan belum tentu memperjelas penyajian pendidik yang 
bersangkutan, bahkan mungkin dapat membingungkan mereka yang berakibat tujuan pembelajaran tidak tercapai.

e. Untuk mempergunakan suatu media pembelajaran tertentu memerlukan persiapan yang baik.

f. Media pembelajaran yang digunakan merupakan bagian dari keseluruhan proses belajar mengajar yang baik.

g. Siswa yang akan menerima penggunaan media pembelajaran oleh pendidiknya harus dipersiapkan sebaik mungkin, sehingga media tersebut dapat membantu mereka lebih aktif terlibat dalam proses belajar mengajar.

h. Jangan menggunakan media pembelajaran sebagai selingan dalam proses belajarmengajar, karena dapat menyimpangkan tujuan utama pengajaran yang dijalankan.

i. Penggunaan media pembelajaran yang telah dipilih hendaknya mampu mengembangkan dan melatih perkembangan siswa, seperti melatih nalar, keterampilan membaca.

Dalam M. Ngalim Purwanto, (2008), Fungsi evaluasi dalam pendidikan dan pengajaran dapat dikelompokan menjadi empat fungsi, yaitu:

a. Untuk mengetahui kemajuan dan perkembangan serta keberhasilan siswa setelah mengalami atau melakukan kegiatanbelajar selama jangka jangka waktu tertentu.

b. Untuk mengetahui keberhasilan program pengajaran.

c. Untuk keperluan Bimbingan dan Konseling (BK).

d. Unttuk keperluan pengembangan dan perbaikan kurikulum sekolah yang bersangkutan.

Demikian betapa peranan dan fungsi evaluasi bagi pengembangan dan perbaikan kurikulu. Penilaian pencapaian kompetensi dasar peserta didik dilakukan berdasarkan indikator. Hal-hal yang perlu diperhatikan dalam penilaian, antara lain:

a. Penilaian diarahkan untuk mengukur pencapaian kompetensi

b. Penilaian menggunakan kriteria, yaitu berdasarkan apa yang dilakukan peserta didik setelah proses pembelajaran

c. Sistem yang dilakukan adalah sistem penilaian yang berkelanjutan

d. Hasil penilaian dianalisis untuk menentukan tindak lanjut, yang berupa perbaikan proses pembelajaran berikutnya.

e. Sistem penilaian yang harus disesuaikan dengan pengalaman belajar yang ditempuh dalam proses pembelajaran.

Tujuan evaluasi dalam pembelajaran Al-Quran-Hadis di Madrasah Ibtidaiyah di antaranya:

a. Memberikan umpan balik kepada guru sebagai dasar untuk memperbaiki program satuan pembelajaran

b. Menentukan haasil kemajuan belajar siswa

c. Menempatkan siswa dalam situasi belajar mengajar yang tepat 
d. Mengenal latar belakang psikologis, fisik, dan lingkungan siswa.

Jenis-jenis Evaluasi dalam pembelajaran Al-Quran-Hadis sebagai berikut:

a. Penilaian formatif, yaitu penilaian yang dilakukan pada setiap akhir pembelajaran

b. Penilaian sumatif, yaitu penilaian yang dilakukan tiap semester

c. Penilaian penempatan, berfungsi untuk menempatkan siswa dalam situasi belajar mengajar yang tepat

d. Penilaian diagnosa, berfungsi untuk memecahkan masalah atau kesulitan belajar siswa.

Metode penilaian di sekolah dalam pembelajaran Al-Quran Hadis dapat berbentuk, antara lain:

a. Tes tulis merupakan penilaian ini digunakan untuk mengukur kemampuan kognitif siswa dalam memahami matteeri quran hadis. Penilaian kinerja dapat diarahkan pada:

1. Kemampuan mengemukakan pendapat

2. Kemampuan bekerja sama

3. Partisipasi dalam diskusi

4. Kemampuan menanggapi masalah

b. Portofolio merupakan penilaian ini ditujukan untuk mengukur kemampuan kreatifitas dibidang seni kaligrafi.

Sikap/performen penilaian ini dapat dilakukan pada waktu siswa melaksanakan pembacaan Al-Quran (cara membacanya, duduknya, bacaannya dan sebagainya). Pada umumnya, untuk menilai hasil belajar siswa di sekolah, guru mempergunakan bermacam-macam bantuk. Akan tetapi observasi memegang peranan penting sebagai alat evaluasi.

\section{B. Metode Penelitian}

Jenis penelitian yang penulis gunakan adalah penelitian kepustakaan (libarary research) yaitu penelitian yang dilakukan oleh seorang penulis dengan cara mengumpulkan data-data yang bersumber dari sebuah buku, jurnal, kitab, artikel, dan tulisan tertentu. (Rusdi Pohan, 2007: 85). Penelitian kepustakaan ini digunakan untuk mengurangi sedikit masalah yang terjadi di lapangan khususnya di dunia pendidikan yang mencakup aspek konseptual-teoritis, baik tentang tokoh pendidikan, atau konsep tertentu seperti tujuan, metode, dan sebuah lingkungan pendidikan. (Sarjono, dkk, 2008: 21). Penelitian dengan pendekatan ini tentang relevansi kurikulum dalam mata pelajaran al-Qur'an Hadis dengan standard isi dianalisis secara kritis dengan menggabungkan tiga ranah belajar yaitu ranah kognitif, afektif dan psikomotorik. Sehingga penilaian teruji dan terukur secara jelas sesuai dengan standard kompetensi yang telah ada.

\section{Hasil Penelitian dan Pembahasan}

Adapun temuan analisis penelitian tentang telaah kurikulum dalam mata pelajaran al-Qur'an Hadis ditingkat Madrasah Ibtidaiyah. Dari landasan teori mata pelajaran Al- 
Qur'an Hadits pada Madrasah Ibtidaiyah kelas 1, 2, dan 3 yang telah penulis jelaskan di atas. Maka dapat penulis analisis sebagai berikut:

a. Bagi kelas 1 semester 1 dan II

Untuk kompetensi dasar yang disajikan di kelas 1 belum bisa dilaksanakan secara maksimal karena kompetensi dasar tersebut menyebutkan peserta didik diharuskan dapat melafalkan dan menghafalkan ayat-ayat pendek secara benar dan fasih. Benar dan fasih di sini berarti peserta didik diharuskan tahu tentang ilmu tajwid, padahal kita tahu usia kelas 1 pada umumnya belum menguasai ilmu tajwid secara mendalam. Oleh karena itu, diharapkan pendidik lebih aktif dalam membimbing peserta didik untuk mencapai kompetensi dasar yang diharapkan.

Kemudian pemahaman hadits tentang kebersihan yang disajikan di atas berdasarkan komopetensi dasar sudah efektif yang perlu dikoreksi oleh pendidik adalah bagaimana bisa membuat peserta didik menerapkan hadits tersebut dalam kehidupan sehari-hari. Dalam hal ini menurut penulis pendidik harus ikut serta dalam memberi contoh hadits tersebut kepada peserta didik. Misalnya hadits tentang kebersihan artinya pendidik hendaknya menyuruh peserta didik untuk selalu membuang sampah pada tempatnya, menyapu ruangan kelas sebelum jam pelajaran dimulai, mencuci tangan sebelum makan.

Begitu juga dengan pemahaman huruf-huruf hijaiah dan tanda bacanya sudah sesuai dengan kompetensi dasar. Sehingga diharapkan pendidik lebih aktif dalam membimbing peserta didik untuk mencapai kompetensi dasar yang diharapkan.

\section{b. Bagi kelas 2 semester 1 dan II}

Untuk pembahasan huruf hijaiah, kaidah ilmu tajwid dan pemahaman hadits kepada orang tua sudah sesuai dengan kompetensi dasar, tinggal pendidik bagaimana menyampaikan pembelajaran yang dapat diterima oleh peserta didik sehingga dapat diterapkan pada kehidupan sehari-harinya. Kemudian untuk menghafal surah-surah pendek sama dengan analisis kelas 1 yang tertera di atas cuman pada surah Al-asr hanya menyebutkan lafalnya saja tanpa adanya penjelasan pada surah tersebut. Maka dari itu tugas pendidik harus memberi kekurangan dari pembahasan tersebut untuk menyesuaikan kompetensi dasar yang diharapkan.

c. Bagi kelas 3 semester 1 dan II

Pada kelas 3 untuk kompetensi dasar yang menekankan peserta didik untuk dapat memahami isi kandungan tentang beberapa ayat pendek cukup efektif diingat usia 
peserta didik yang dirasa sudah mampu untuk menangkap maksud dari ayat yang disampaikan. Namun untuk kompetensi dasar yang mengharuskan peserta didik untuk lebih bisa mendalami tentang ilmu tajwid kami rasa belum maksimal, ini dikarenakan peserta didik pada kelas 3 biasanya hanya bisa menghafalkan tanpa bisa menerapkan dalam bacaan Al-Qur'an.

\section{Kesimpulan dan Saran}

\section{Kesimpulan}

Berdasarkan hasil penelitian yang disimpukan ini akan dikemukakan beberapa implikasi yang dianggap relevan dengan penelitian, implikasi tersebut antara lain sebagai berikut :

a. Kurikulum mata pelajaran al-Qur'an hadis yang disusun harus menunjukkan ciri dan spesifik ke daerahan baik dalam bentuk geografis maupun kebudayaan.

b. Benar dan fasih di sini berarti peserta didik diharuskan tahu tentang ilmu tajwid, padahal kita tahu usia kelas 1 pada umumnya belum menguasai ilmu tajwid secara mendalam. Oleh karena itu, diharapkan pendidik lebih aktif dalam membimbing peserta didik untuk mencapai kompetensi dasar yang diharapkan.

c. Untuk pembahasan huruf hijaiah, kaidah ilmu tajwid dan pemahaman hadits kepada orang tua sudah sesuai dengan kompetensi dasar, tinggal pendidik bagaimana menyampaikan pembelajaran yang dapat diterima oleh peserta didik sehingga dapat diterapkan pada kehidupan sehari-harinya.

d. Kompetensi dasar yang menekankan peserta didik untuk dapat memahami isi kandungan tentang beberapa ayat pendek cukup efektif diingat usia peserta didik yang dirasa sudah mampu untuk menangkap maksud dari ayat yang disampaikan.

\section{Saran}

Beberapa saran yang akan penulis tawarkan dalam jurnal ini dalam penulisan ini masih belum secara mendalam menelaah kurikulum dalam mata pembelajaran AlQur'an Hadis terutama pada komparasi dengan kurikulum K13 sekarang ini. Untuk penulis selanjutnya bisa menulis jurnal dengan membandingkan KTSP dengan K13.

\section{Daftar Pustaka}

Departemen Agama RI. (2006). Kurikulum 2006, Pedoman Umum Pengembangan Silabus Madrasah Ibtidaiyah. Jakarta: Direktorat Jenderal Kelembagaan Agama Islam.

Direktorat Pendidikan Madrasah. (2007). Model Kurikulum Tingkat Satuan Pendidikan (KTSP) Madrasah Ibtidaiyah. Jakarta: Depag.

Efferi Adri. (2009). Materi dan Pembelajaran Qur'an Hadits Mts-MA. Kudus: STAIN Kudus. 
Fahrurozi. (2016). Telaah Kurikulum Al-Qur'an Hadits Kelas IV Semester II Madrasah Ibtidaiyah, (Online). Pada Tanggal 16 April 2016.

Joko Susilo, Muhammad. (2008). Kurikulum Tingkat Satuan Pendidikan, Cet. I. Jakarta: PT. Medyatama Pustaka Pelajar.

LPTK Fakultas Tarbiyah IAIN Sunan Ampel. (2009). Diklat Profesi Guru, Surabaya: tp.

Majid, Abdul. (2013). Strategi Pembelajaran, Bandung: PT Remaja Rosdakarya.

Mudjijo. (1995). Tes Hasil Belajar, Jakarta: tp.

Purwanto M. Ngalim. (2008). Prinsip-Prinsip dan Teknik Evaluasi Pengajaran, Bandung: tp.

Ridwan Abdullah Sani. (2013). Inovasi Pembelajaran. Jakarta: PT. Bumi Aksara.

Supriadie Didi \& Deni Darmawan. (2012). Komunikasi Pembelajaran. Bandung: PT Remaja Rosdakaraya.

Pohan Rusdi. (2007). Metodologi Penelitian Pendidikan. Yogyakarta: Ar-Rijal Institut.

Sarjono, dkk. (2008). Panduan Penulisan Skripsi. Yogyakarta: Jurusan PAI FTK UIN Sunan Kalijaga. 